\title{
GSR wt Allele
}

National Cancer Institute

\section{Source}

National Cancer Institute. GSR wt Allele. NCI Thesaurus. Code C157041.

Human GSR wild-type allele is located in the vicinity of $8 \mathrm{p} 12$ and is approximately $50 \mathrm{~kb}$ in length. This allele, which encodes glutathione reductase, mitochondrial protein, is involved in cellular glutathione homeostasis. Mutation of the gene is associated with hemolytic anemia due to hereditary glutathione reductase deficiency. 